\title{
A photographic and acoustic transect across two deep-water seafloor mounds, Mississippi Canyon, northern Gulf of Mexico
}

\author{
Patrick E. Hart ${ }^{\mathrm{a}, *}$, Deborah R. Hutchinson ${ }^{\mathrm{b}}$, Joan Gardner ${ }^{\mathrm{c}}$, Robert S. Carney ${ }^{\mathrm{d}}$, Dan Fornari ${ }^{\mathrm{e}}$ \\ ${ }^{a}$ U.S. Geological Survey, 345 Middlefield Road, Mail Stop 999, Menlo Park, CA 94025, USA \\ ${ }^{\mathrm{b}}$ U.S. Geological Survey, Woods Hole, MA 02543, USA \\ ${ }^{\mathrm{c}}$ Naval Research Laboratory, Washington, DC 20375, USA \\ ${ }^{\mathrm{d}}$ Coastal Ecology Institute, Louisiana State University, Baton Rouge, LA 70803, USA \\ ${ }^{\mathrm{e}}$ Woods Hole Oceanographic Institution, Woods Hole, MA 02543, USA
}

\section{A R T I C L E I N F O}

\section{Article history:}

Received 4 May 2007

Received in revised form 28 June 2007

Accepted 28 January 2008

\section{Keywords:}

Gas hydrate

Seafloor mounds

Side-scan sonar

Multibeam bathymetry

Near-bottom photography

Chemosynthetic communities

\begin{abstract}
A B S T R A C T
In the northern Gulf of Mexico, a series of seafloor mounds lie along the floor of the Mississippi Canyon in Atwater Valley lease blocks 13 and 14. The mounds, one of which was drilled by the Chevron Joint Industry Project on Methane Hydrates in 2005, are interpreted to be vent-related features that may contain significant accumulations of gas hydrate adjacent to gas and fluid migration pathways. The mounds are located $\sim 150 \mathrm{~km}$ south of Louisiana at $\sim 1300 \mathrm{~m}$ water depth.. New side-scan sonar data, multibeam bathymetry, and near-bottom photography along a $4 \mathrm{~km}$ northwest-southeast transect crossing two of the mounds (labeled D and F) reveal the mounds' detailed morphology and surficial characteristics. Mound D, $\sim 250 \mathrm{~m}$ in diameter and $7-10 \mathrm{~m}$ in height, has exposures of authigenic carbonates and appears to result from a seafloor vent of slow-to-moderate flux. Mound F, which is $\sim 400 \mathrm{~m}$ in diameter and $10-15 \mathrm{~m}$ high, is covered on its southwest flank by extruded mud flows, a characteristic associated with moderate-to-rapid flux. Chemosynthetic communities visible on the bottom photographs are restricted to bacterial mats on both mounds and mussels at Mound D. No indications of surficial gas hydrates are evident on the bottom photographs.
\end{abstract}

Published by Elsevier Ltd.

\section{Introduction}

For the past three decades, marine geoscientists have studied naturally occurring gas hydrates in continental slope sediments worldwide. It is well known that hydrates formed from natural gas can occur in water depths greater than a few hundred meters in a zone extending from the seafloor to a sub-bottom depth determined primarily by the temperature gradient, pressure regime, pore-water salinity, and availability of methane. The total volume of natural gas stored within the marine hydrate stability zone is enormous, although estimates vary widely (Kvenvolden, 1993; Milkov and Sassen, 2003). In recent years, research has dramatically escalated across a broad spectrum of investigations of the potential of gas hydrate as an energy resource and the possibility that subbottom gas hydrate deposits may pose a geohazard to deep-water oil and gas drilling and production. These studies also contribute to knowledge about the role of gas hydrate in climate change.

\footnotetext{
* Corresponding author. Tel.: +1 650329 5160; fax: +1 6503295190.

E-mail address: hart@usgs.gov (P.E. Hart).
}

Gas hydrate research is particularly important in the northern Gulf of Mexico owing to the oil and gas exploration and production throughout the region. Drilling is now routinely conducted in deepwater areas of the continental slope where gas hydrate is stable. It is critical to understand what effect drilling through gas hydrate zones has on slope stability and on the safety of wells, pipelines, and platforms (Hovland and Gudmestad, 2001). Before either the geohazard or resource potential of gas hydrate in the northern Gulf of Mexico can be evaluated, a much better understanding of its distribution and concentration within the gas hydrate stability zone is needed. To achieve this, the Chevron Joint Industry Project (JIP) investigated gas hydrate targets in the northern Gulf of Mexico during a drilling expedition in 2005.

One of the focus sites for the 2005 JIP drilling lies within the Mississippi Canyon in $\sim 1300 \mathrm{~m}$ of water in Atwater Valley lease blocks 13 and 14 (Fig. 1). This study area contains several seafloor mounds that may be vent features with associated accumulations of gas hydrate (Snyder et al., 2004). Prior to the 2005 JIP drilling, several research cruises, led by the U.S. Geological Survey, the Naval Research Laboratory, and the Woods Hole Oceanographic Institution, have investigated this site and collected high-resolution seismic reflection data (Hutchinson and Hart, 2004), piston cores, 


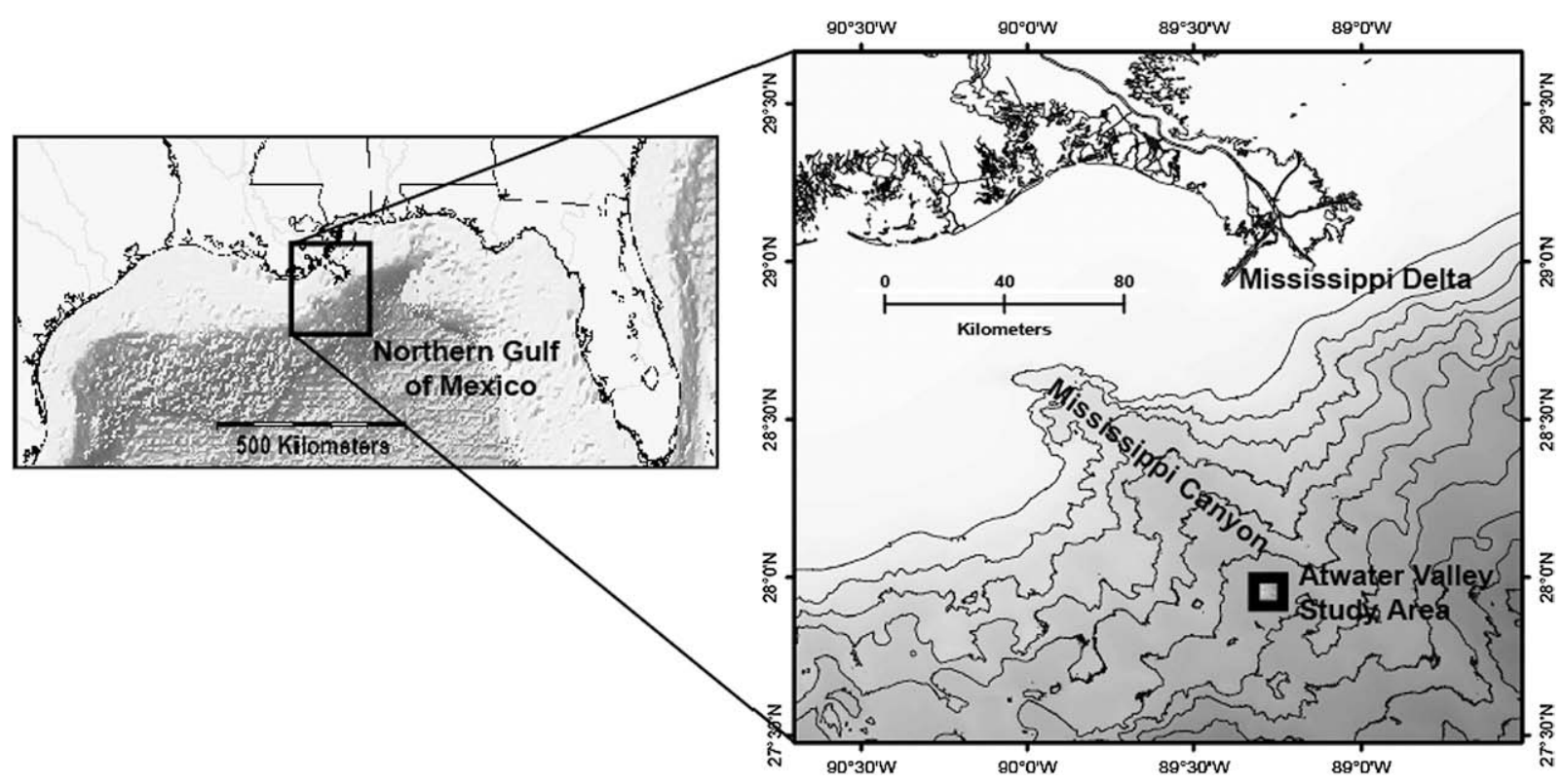

Fig. 1. Location map showing the Atwater Valley gas hydrate study area $\sim 150 \mathrm{~km}$ south of Louisiana along the floor of the Mississippi Canyon at a water depth of $\sim 1300$ m.

heat flow measurements (Coffin et al., 2008), electromagnetic readings (Ellis et al., 2008), near-bottom photographs (Evans et al., 2004), side-scan sonar, and multibeam bathymetry data. WesternGeco has also provided recently reprocessed 3D seismic data coverage of the area to the JIP, giving an excellent picture of the deep geologic framework beneath the mounds. Integrated interpretation of these data sets led to the selection of the Atwater Valley sites for the 2005 JIP drilling program (Claypool, 2006). This program investigated the interpretation that gas hydrate accumulations exist along and adjacent to the fault-related pathways for fluids and gas that vent at the seafloor, resulting in the Atwater Valley mounds (Fig. 2).

Seafloor mounds with associated gas hydrate deposits have been detected and studied across the northern Gulf of Mexico continental slope using 2D and 3D seismic data, multibeam bathymetry, piston coring, and observations from manned submersibles (e.g., MacDonald et al., 2003; Roberts and Carney, 1997; Roberts, 2001; Sager et al., 2003, 2004; Sassen et al., 1999). Roberts and Carney (1997) conclude that the mounds result from episodic, fault-controlled fluid venting and associated sediment expulsion. They have established a qualitative classification of northern Gulf of Mexico seafloor mounds based on inferred fluid flux rates ranging from rapid flux (venting) mud-prone sites to slow flux (seepage) mineral-prone sites. In this paper we examine the characteristics of the Atwater Valley seafloor Mounds D and F as revealed by acoustic and photographic observations and classify the mounds according to the criteria of Roberts and Carney (1997).

\section{Geologic setting}

Mounds D and $\mathrm{F}$ lie on the gently sloping floor (less than $1^{\circ}$ ) of the Mississippi Canyon near where the canyon meets the uppermost extent of the Mississippi fan. At more than $150 \mathrm{~km}$ long and generally $\sim 10-15 \mathrm{~km}$ wide, the Mississippi Canyon is one of the most prominent features on the continental slope in the northern Gulf of Mexico. The canyon is the most recently active pathway to deliver sediment from the large drainage basin of the Mississippi River to the deep Gulf of Mexico (Weimer, 1991). It cuts across the salt withdrawal mini-basins of the continental slope, indicating its young age. Although relief along the canyon is more than 300$400 \mathrm{~m}$ in the upper slope, the canyon walls generally have less than
$100 \mathrm{~m}$ relief in the vicinity of Mounds $\mathrm{D}$ and $\mathrm{F}$ and disappear $\sim 35 \mathrm{~km}$ south of the Atwater Valley drill sites.

The Mississippi Canyon developed seaward of the ancestral Mississippi Delta that was located near the shelf edge during the last glacial sea-level lowstand (Coleman et al., 1983; Suter and Berryhill, 1985). Deposits within the canyon record a complex history of cut and fill dominated by mass movement processes and gravity-driven flow until $\sim 7.5 \mathrm{ka}$, when hemipelagic clay

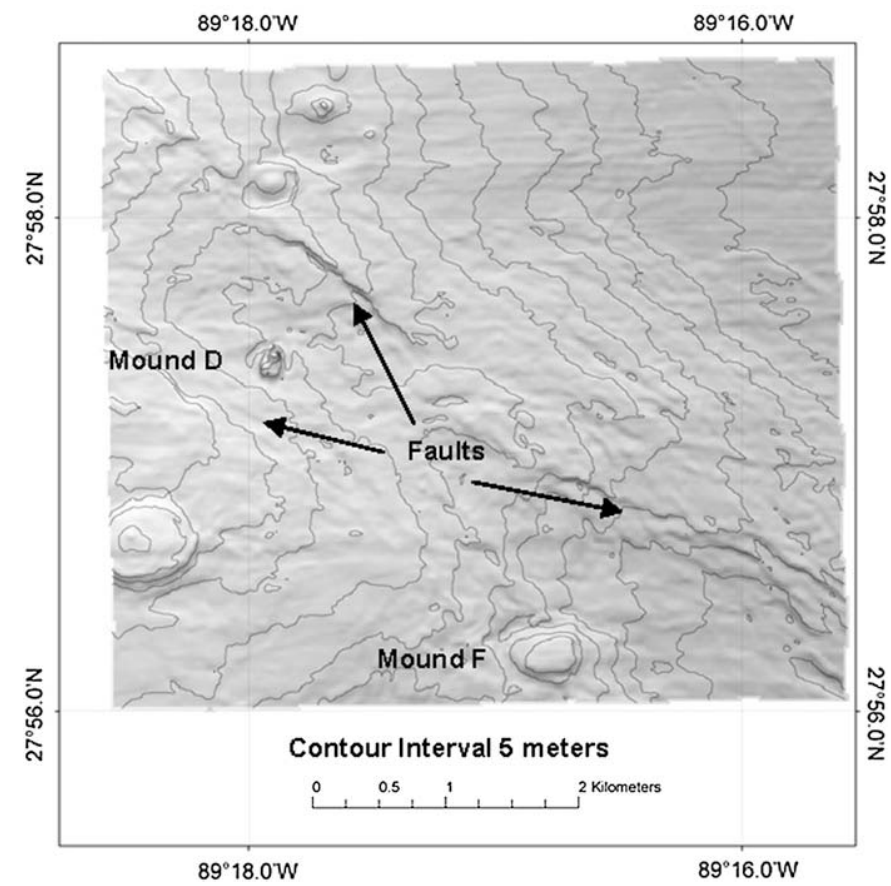

Fig. 2. Shaded bathymetric relief image of the Atwater Valley JIP study area. The bathymetry used to create this image was calculated from the seafloor reflection time of the WesternGeco 3D seismic survey reprocessed for the JIP. The boundaries of this image are the limits of the reprocessed 3D survey. Low-relief northwest-southeas trending lineaments are interpreted to be the surface expression of faults that create a shallow graben-like structure containing Mounds D and F. Bathymetric contour interval is $5 \mathrm{~m}$. 
drape up to $20 \mathrm{~m}$ thick became the dominant deposit (Goodwin and Prior, 1989; Coleman et al., 1983). Continued salt withdrawal associated with extensional subsidence occurs within and around the canyon, with stratigraphic sliding evident along the canyon edges (Cooper and Hart, 2002). The extremely high depositional rates, more than 600-700 m since Late Pleistocene time (Goodwin and Prior, 1989), together with the complex, heterogeneous fill, highlight the dynamic geological environment in which Mounds D and F occur.

The bathymetry of the Mississippi Canyon floor adjacent to Mounds D and F dips gently to the southeast. Although this region is flat compared to rest of the Northern Gulf of Mexico continental slope, there are observable surficial features in addition to the seafloor mounds, including a northwest-southeast trending graben-like structure that is bounded by the surface expression of a set of sub-parallel faults. Wood et al. (2008) interpret a set of seismic profiles from NRL, the USGS, and WesternGeco, along a northwest-southeast transect running through Mounds D and F. They conclude that the shallow subsurface is cut by a network of faults that are likely related to an active salt diapir that crests several hundred meters below the seafloor. The faults are postulated to provide migration pathways for warm fluid and gas and mobilized sediment to vent at the seafloor, giving rise to the observed seafloor mounds. Wood et al. (2008) also provide evidence for localized accumulations of free gas beneath the mounds. The presence of free gas in the shallow subsurface requires some explanation. Laterally uniform heat flow values would place the base of the gas hydrate stability (BGHS) zone well below the free gas reported by Wood et al. (2008). Natural gas above the BGHS should be in the form of gas hydrate. However, Coffin et al. (2008) report significantly elevated heat flow values at the mounds $160 \mathrm{~mW} / \mathrm{m}^{2}$ at Mound $\mathrm{F}$ and $132 \mathrm{~mW} / \mathrm{m}^{2}$ at Mound $\mathrm{D}$ - compared with $40-50 \mathrm{~mW} / \mathrm{m}^{2}$ background values away from the mounds. This would perturb the BGHS upward towards the seafloor beneath the mounds, allowing shallower than expected occurrence of free gas and support the interpretation that there is active or recent venting of warm fluid and gas at Mounds D and F (Wood et al., 2008). Kastner et al. (2008) report elevated salinity in the vicinity of Mound F, which could also contribute to shoaling of the BGHS.

\section{Biologic setting}

Chemosynthetic communities subsisting in high sulfide habitats on continental slopes typically consist of mats of Beggiatoa or related microbes along with some combination of symbiotehosting metazoans: vestimentiferan tubeworms, bathymodiolid mussels, and vesycomyid clams (Carney, 1994; Cordes et al., 2007). The tubeworms and mussels are sessile and live attached, while the clams move freely through the sediments. Sulfide is the primary energy source for most, although direct utilization of methane has been proven in some and is suspected for others. The required sulfide is often produced by anaerobic microbial oxidation of methane; thus the flux of methane and sulfide are linked. In the Gulf of Mexico, chemosynthetic communities are most often associated with exposed authigenic carbonates. The presence of carbonates provides a substrate for attachment and is an indication that anaerobic microbial oxidation of methane at the location has been persistent, an important temporal factor in biological community development.

Brine flow within sediments and brine ponding on the seafloor are less common than authigenic carbonate outcroppings but are features of seepage in salt provinces. The relationship between brines in surficial sediments and chemosynthetic fauna is inconsistent and remains to be fully understood. In some instances extensive communities exist at such brine-related features as seafloor brine pools (MacDonald et al., 1990). Other features such as the Orca Basin brine lake apparently lack any such communities (Brooks et al., 1990). The underlying cause may be chemical differences in the brines (Aharon et al., 1992; Joye et al., 2005). Communities dominated by chemosynthetic mussels seem to be most extensively developed where the brine is methane charged and sulfate depleted.

\section{Methods}

The first Atwater Valley data set reviewed by the JIP was a 3D data volume acquired by WesternGeco in 1998. WesternGeco reprocessed this data set in 2002 to help locate potential gas hydrate drilling targets. Based on identification of seismic reflections interpreted as gas hydrate accumulations beneath Mound F (Snyder et al., 2004), the site was selected as one of the locations for the 2005 JIP Gulf of Mexico drilling and coring program. The results described in this paper were acquired at the Atwater Valley mounds in June 2004 aboard the $R / V$ Pelican as part of a cruise led by the Woods Hole Oceanographic Institution. As detailed above, this was one of several pre-drilling research cruises carried out to provide geological information about the mounds and to investigate which techniques held the most promise for identifying and characterizing different types of Gulf of Mexico hydrate deposits.

During the $R / V$ Pelican cruise, researchers collected several controlled-source electromagnetic profiles over the mounds and more than 6000 bottom photographs (Evans, 2004; Evans et al., 2004; Ellis et al., 2008). Fornari (2003) gives a detailed description of the deep-towed digital camera system. The ship locations for the bottom photography camera sled tows are shown in Fig. 3. Because the camera sled was towed at $\sim 1300 \mathrm{~m}$ depth and lacked accurate positioning relative to ship position, locating the camera was problematic. The tow tracks, especially on tracks that were not straight, contain errors in layback and crossline drift of the sled. For

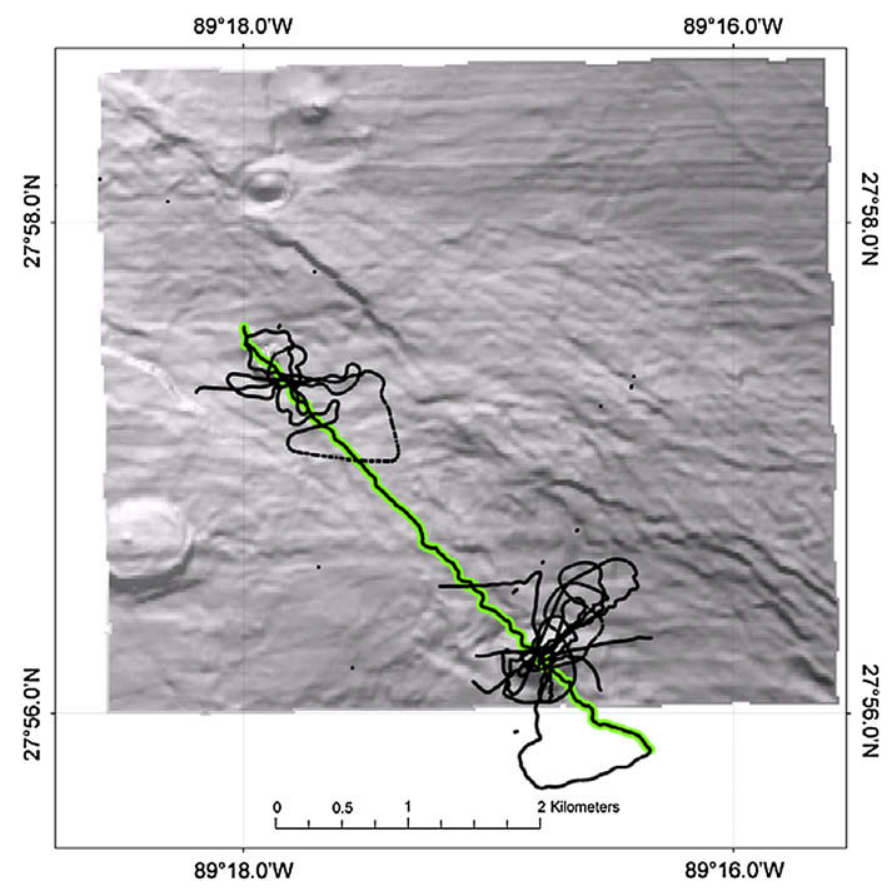

Fig. 3. Ship tracklines of the five bottom photography tows that collected over 6000 images investigating Mounds D and F. Accurate layback distances from the $R / V$ Pelican to the towed camera sled could only be determined for the relatively straight portion highlighted. 
the majority of the photography tracklines where there were frequent turns, it has not been possible to determine reliable seafloor positions for the bottom photos. However, for one relatively straight transect passing over Mounds D and $\mathrm{F}$ and highlighted on Fig. 3, satisfactory positions have been determined by comparing the water depth along the transect measured by a depth sensor on the camera sled with water depth from the multibeam bathymetry survey and the 3D seismic data. The bottom photos interpreted in this paper are from this transect. The camera sled was towed at $\sim 1$ knot and at an elevation of 4-6 $\mathrm{m}$ above the seafloor taking pictures at $10 \mathrm{~s}$ intervals. Scale for the photographs was calculated from the camera height. The calculated scale was confirmed to be accurate within $5 \%$ by inspection of the known width of plow marks left by the dragging of the controlled-source electromagnetic system across the seafloor. These are marks visible on dozens of the photographs.

The bottom photos were reviewed for features relevant to the fluid flux-related genesis of the mounds and their current chemosynthetic communities. Authigenic carbonate exposures and extruded mud flows can be directly observed, as well as bacterial mats and mussels. Examples of these observations are detailed below. Evidence for interstitial brine flows is more interpretative. Interstitial brine carrying sulfide or methane that yields sulfide will alter the composition and texture of sediments by acidic dissolution of carbonates and stain the sediments black with iron sulfides. Much of the sediment covering the mounds appears to have been altered by this process, but we have no direct samples from the $R / V$ Pelican or other cruises to confirm this interpretation.

The Naval Research Laboratory led two additional research cruises to Atwater Valley. In May 2004, a cruise on the R/V Gyre collected 15 piston cores for pore water geochemical analysis and 24 heat flow measurements to determine the geothermal gradient and to constrain the fluid flow regime (Coffin et al., 2008; Wood et al., 2008). A second NRL cruise in February 2005 aboard $R / V$ Pelican acquired coincident side-scan sonar, multibeam bathymetry, and high-resolution chirp sub-bottom data using NRL's DT1 deep-towed mapping system. The DT1 system contains side-scan sonar and sub-bottom chirp profiler sensor arrays, as well as multibeam bathymetric sensors housed in a neutrally buoyant $2000 \mathrm{lb}$ towfish. Motion and depth sensors are also integrated in the system to monitor pitch, roll, yaw and heave. The DT1 system was towed at $\sim 3$ knots at $\sim 50 \mathrm{~m}$ above the seafloor. The DT1 side-scan sonar system provided high-resolution, low-noise imagery at 120 and $410 \mathrm{kHz}$ with an approximate swath width of $300 \mathrm{~m}$ per side for this survey, and the $200 \mathrm{kHz}$ multibeam bathymetric mapping system collected $350-\mathrm{m}$ wide swaths. Thirteen survey lines, each $\sim 8 \mathrm{~km}$ in length, were completed over the Atwater site. Survey line spacing was $\sim 200 \mathrm{~m}$ apart, with lines being extended beyond the mounds by a minimum of $2 \mathrm{~km}$ to ensure the tow-vehicle passed over them before a turn was initiated. An ultra-short baseline navigation system was used to locate the DT1 system during data acquisition, but problems with the navigation system resulted in zones of insufficient swath overlap and gaps in the resulting data coverage. These gaps can be seen in the map view image of the side-scan data shown in Fig. 4.

\section{Results and discussion}

The side-scan sonar backscatter data at Mounds D and F (Figs. 5 and 6) show regions of high or strong backscatter (represented by darker pixels on the charts) and regions of low or weak backscatter (represented by lighter pixels). Mound D is clearly a feature with strong backscatter, indicating a relatively hard or more reflective seafloor, probably the result of the presence of thin carbonate deposits. The bottom photograph in Fig. 7 shows an exposure of authigenic carbonate on the northwest flank of Mound D. It

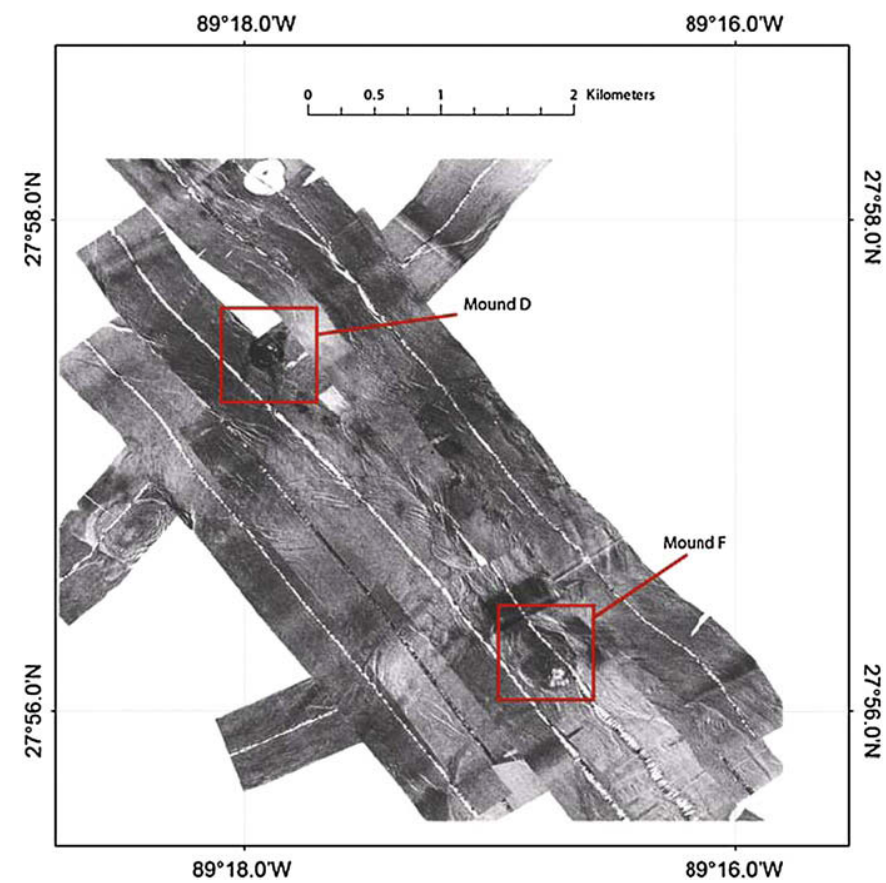

Fig. 4. Mosaiced image of the side-scan sonar data covering the Atwater Valley seafloor mounds. The image has been normalized so that the greyscale is representative of textural changes in the seafloor surface that affects the backscatter intensity. Regions of high or strong backscatter are represented by darker pixels on the charts, and regions of low or weak backscatter are represented by lighter pixels. The red boxes indicate locations of Figs. 5 and 6.

presumably formed in surficial sediments parallel to the seafloor and has been exposed as sediment slid down the flank of the mound. The presence of authigenic carbonate is an indication of the flux rate at the mound. Roberts and Carney (1997) and Roberts (2001) conclude that mineral-prone features such as authigenic carbonates are associated with relatively slow fluid flux. The carbonate exposures at Mound D are not widespread and do not show large cones or chimneys, suggesting that the Mound D fluid

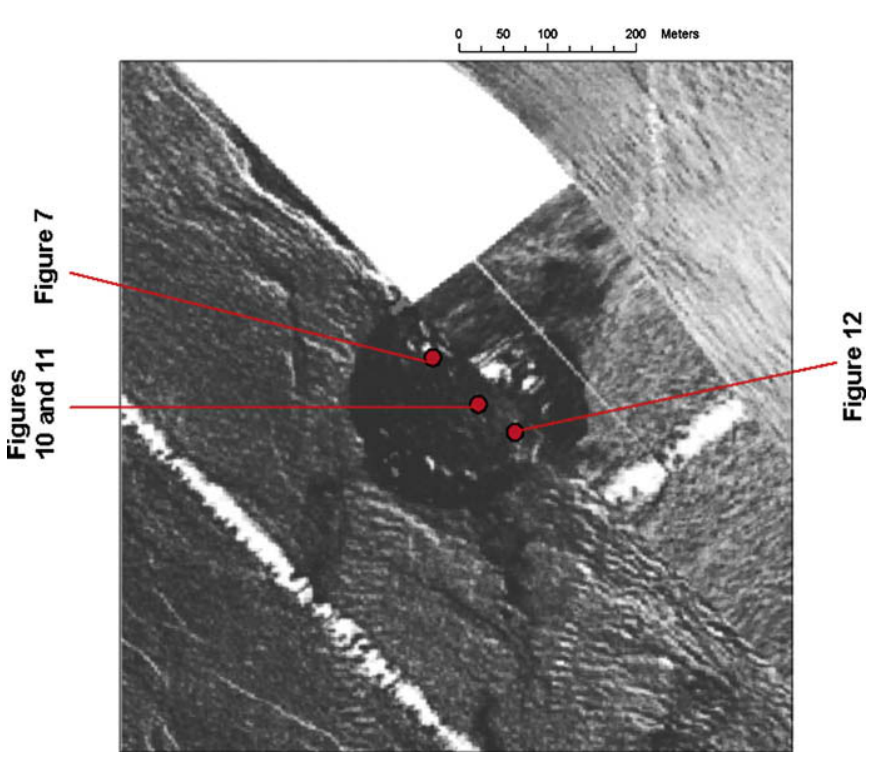

Fig. 5. Side-scan sonar data at Mound D showing much higher backscatter values (darker pixels) than the adjacent valley floor. The locations of the bottom photographs in Figs. 7, 10, 12, and 13 are indicated by the red dots. 


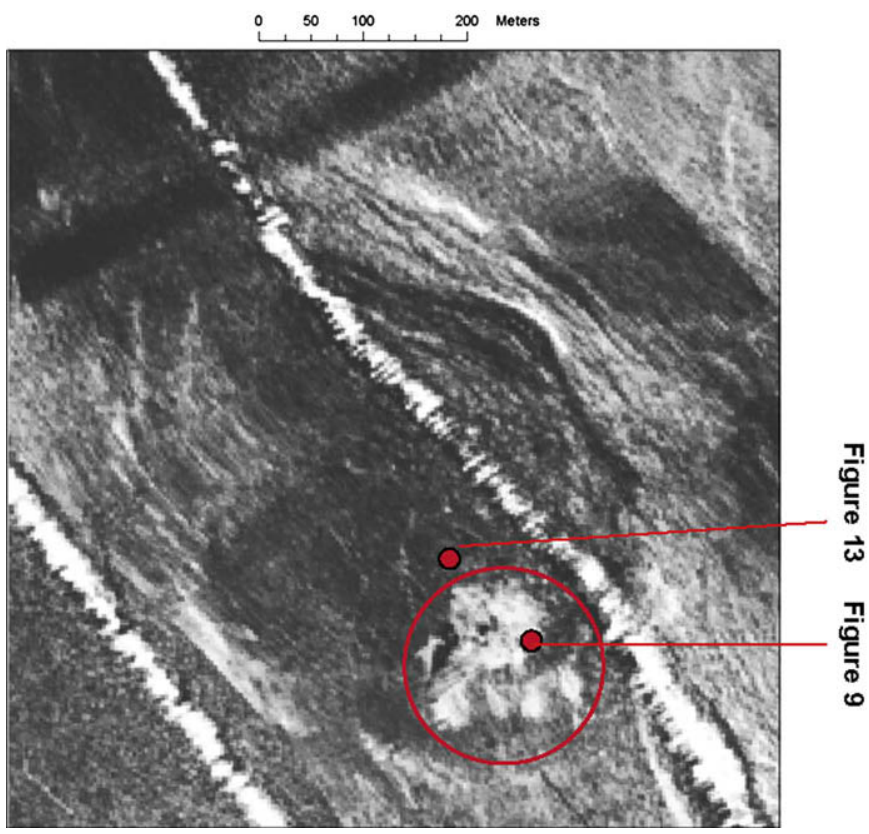

Fig. 6. Side-scan sonar data at Mound F. The low backscatter area (lighter pixels) on the southwest flank of the mound within the red circle is interpreted to be a mud flow. The locations of the bottom photographs in Figs. 9 and 11 are indicated by the red dots.

flux is slow-to-moderate according to the Roberts and Carney (1997) classification.

Figs. 6 and 8 show the backscatter signature covering most of Mound $\mathrm{F}$ to be stronger than the surrounding valley floor, but weaker or lower intensity than at Mound D. Fig. 8 is an oblique view of a 3D image created by merging the backscatter and multibeam bathymetry data, displayed at 8:1 vertical exaggeration. An area of low backscatter evident on the southeast rim and flank of the mound can be identified as a mud flow on the photograph in Fig. 9. This localized small-scale mud flow indicates that Mound $\mathrm{F}$ was more mud-prone prior to our surveys and that it may be associated with more rapid fluid flux than Mound D. However, this mud flow is not part of a large mud volcano that Roberts and Carney (1997) use

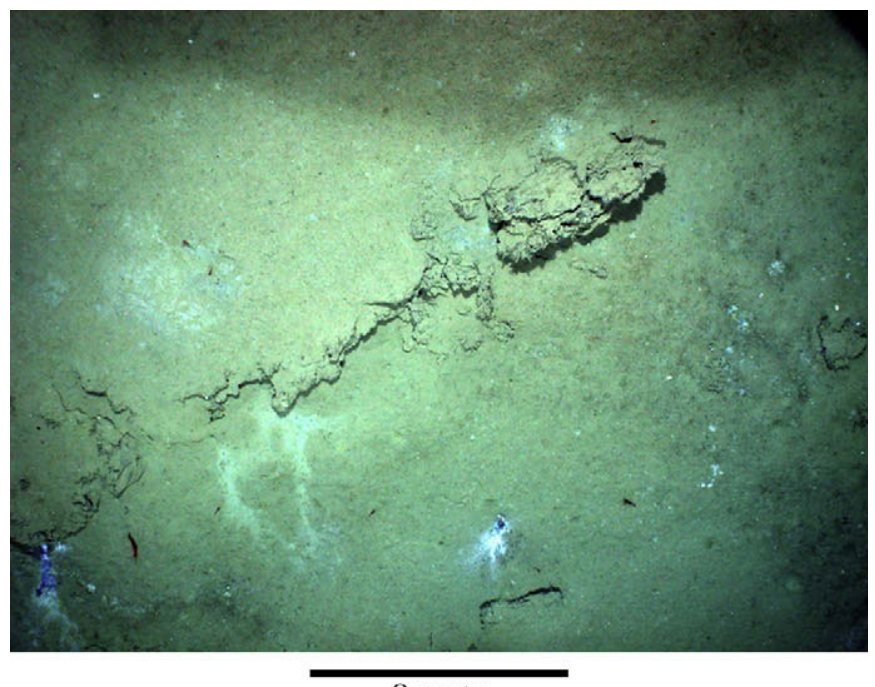

One meter

Fig. 7. Authigenic carbonate exposure on the flank of Mound D. The light-brown sediments surrounding the exposure result from thoroughly oxidized iron and organics in the uppermost few centimeters of sediment.

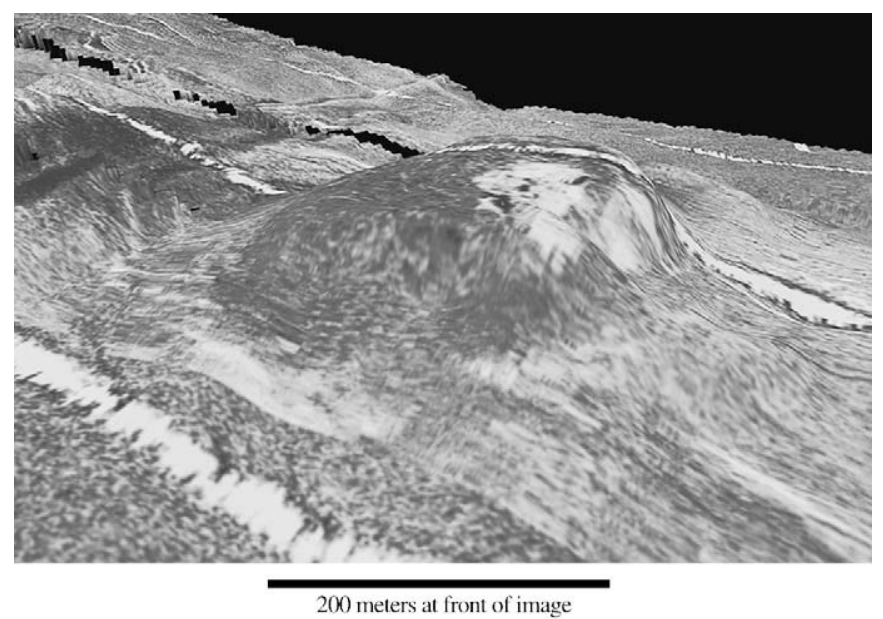

Fig. 8. Oblique view from the southwest of a 3D image of Mound F displayed at 8:1 vertical exaggeration. This image was created by merging the side-scan sonar backscatter data with the multibeam bathymetry. The light-colored area on the flank of the mound is interpreted to be an extruded mud flow.

to classify a mound as rapid fluid flux. Mound $\mathrm{F}$ is interpreted here to be the result of moderate-to-rapid fluid flux. No exposed carbonates are observed on the dense coverage of bottom photographs across Mound F, although it is possible that thin crusts could exist just below the surface.

Although our interpretation of surficial mud flows at Mound $\mathrm{F}$ is based on seafloor observations, this conclusion is supported by analysis of cores from the Atwater JIP drilling and coring program (Yun et al., 2006). They have classified the shallow sediments at Mound F as inorganic clays of high plasticity and state that Atwater drill site \#13 shows fluid and sediment intrusion and venting. Their results show water content to be fairly uniform to depths greater than 150 mbsf. Francisca et al. (2005) note that water content is generally expected to decrease with depth, but that cores recovered from three gas hydrate and/or mud volcano sites in the Gulf of Mexico (Garden Banks GB425, Mississippi Canyon MC852, and Green Canyon GC185) have relatively uniform water content at lower average values $(<70 \%)$ than distal areas $(>80 \%)$. They also

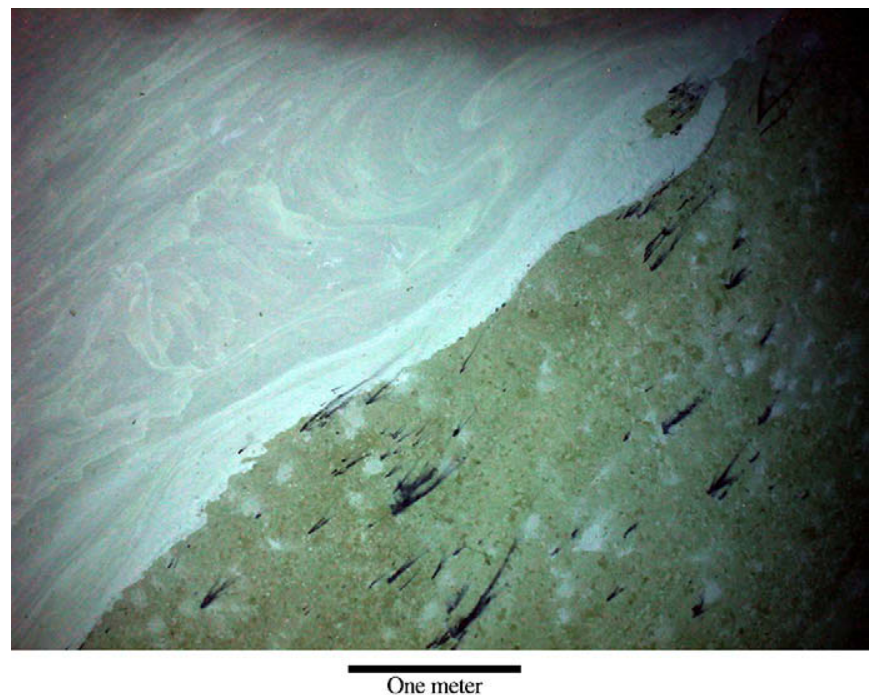

Fig. 9. The edge of an extruded mud flow on the flank of Mound F (very light-colored sediments in upper-left half of picture) covering light-brown sediments more typical of this area. 
report elevated pore water salinities, which they attribute to brines from underlying salt. They postulate that the physical properties of the sediments on these mounds (strength, stiffness, and porosity) are not governed by overburden effective vertical stress, but instead by electrostatic forces caused by the interaction of the high pore water salinities and the high specific surface of the clay sediment grains. The Atwater mounds also overlie salt (Wood et al., 2008) and pore water samples from the cores have high salinities (Yun et al., 2006), which suggest that Mound F is likely to be similar in origin to the sites discussed in Francisca et al. (2005), and that mounds with associated mud flows may be widespread along the continental slope of the northern Gulf of Mexico.

The broad dark areas observed in images from both mounds are interpreted to be caused by brine flux through the seafloor. The typical seafloor at the depths of the mounds consists of hemipelagic sediments. Within a centimeter or two of the sediment-water interface thoroughly oxidized iron and organics produce a characteristic light-brown color (Figs. 7 and 9). We speculate that below this brown layer organics are partially consumed, and more reduced forms of iron produce a light grey to light blue-green color in the sediments (Figs. 10 and 11). Images of such a seafloor primarily show the upper layer, although bioturbation does bring some lighter-colored sediment to the surface. Black sediments are caused by iron sulfides carried by interstitial brine flows rather than oxides (Fig. 10). Seafloor areas in which the dark bottom is patchy may reflect more complex flow patterns of interstitial brines, recent sedimentation events in which well oxidized sediments were rapidly deposited on top of a black flow channel, or cessation of flow being followed by reoxidization. Claypool (2006), Kastner et al. (2008), and Coffin et al. (2008) give more detailed analysis of the pore water geochemistry at the mounds.

Examination of bottom photographs covering Mounds D and $\mathrm{F}$ found extensive development of bacterial mats (Figs. 12 and 13), but, as noted above, exposed carbonate is only evident on the northwest flank of Mound D. The few carbonate outcrops observed lacked chemosynthetic fauna. Mussels can also be identified at Mound D. A unique aspect of these mussels is that they occur within broad dark areas of seafloor inferred to be brine flows (Figs. 10 and 11). In other parts of the Gulf of Mexico, mussels more

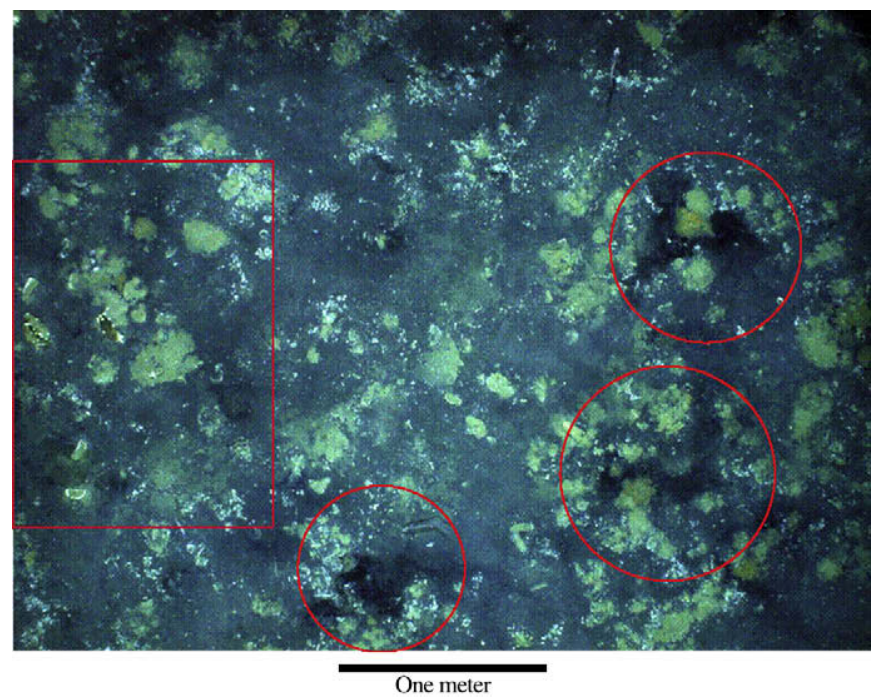

Fig. 10. Mussels on Mound $D$ in an area with surface sediments altered by brine flows. The black sediments within the red circles are caused by iron sulfides carried by interstitial brine flows. The various shades of blue-green sediments with partially consumed organics and more reduced forms of iron than the typical light-brown surface sediments. The red box shows the portion of this photograph displayed at a larger scale in Fig. 11.

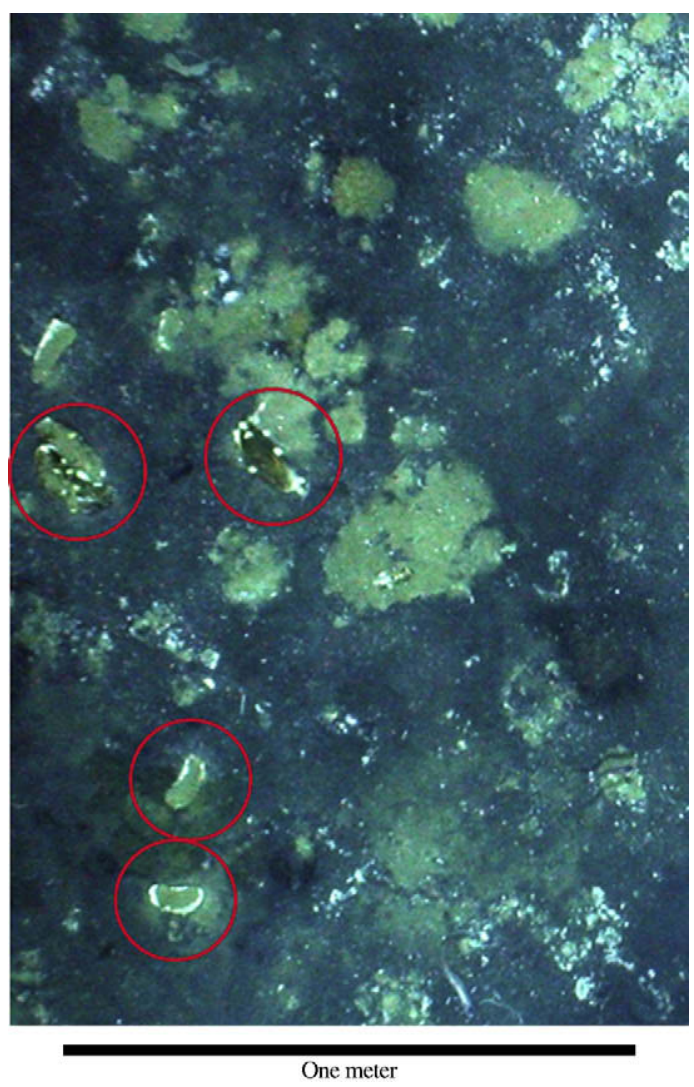

Fig. 11. Blown-up portion of Fig. 10, showing mussels within the red circles.

typically appear at the edge of brine pools and flows (MacDonald et al., 1990). Brine flow features similar to those at Mound D were found at Mound F, but no mussels were observed. Neither vestimentiferan tubeworms nor vesycomyid clams, common chemosynthetic biota, were observed on either mound. Laterally, the transition from brine-influenced to normal soft bottom was abrupt in some areas or passed through a spatial gradient of progressively smaller and rare bacterial mats. Both on the normal

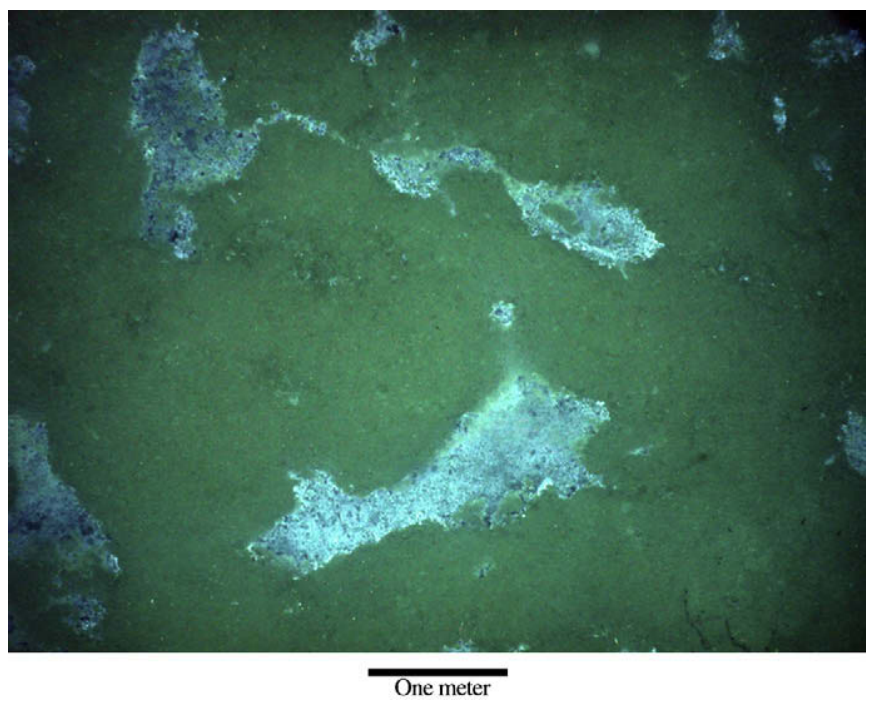

Fig. 12. Bacterial mats (lighter-colored areas) on Mound D. 


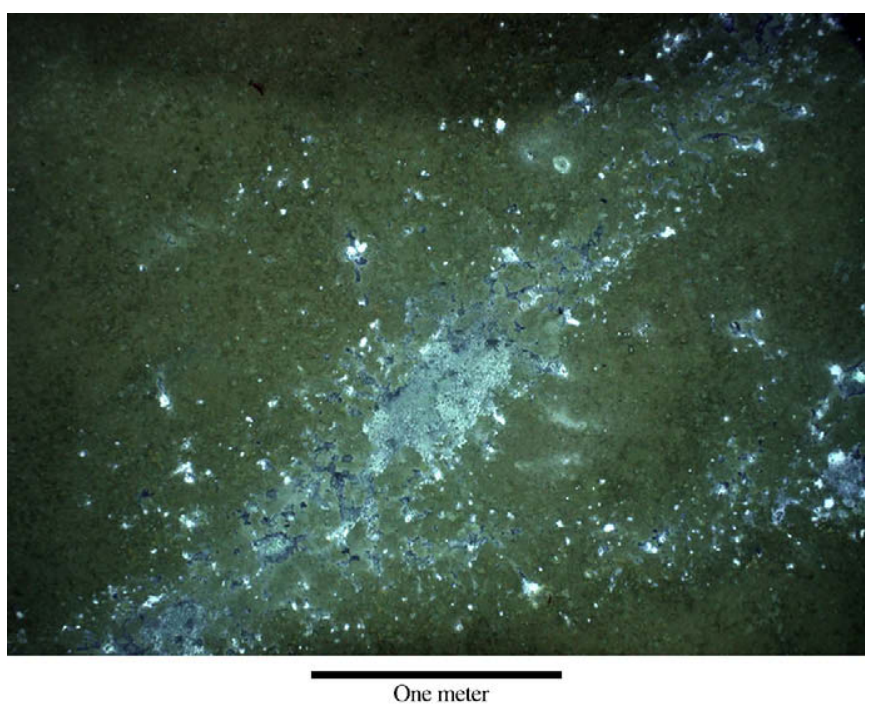

Fig. 13. Bacterial mats (lighter-colored areas) on Mound F.

bottom and in transition areas of mud and bacterial mats, only typical pelagic species were observed. These included shrimp too small to be identified, rattail fishes and a variety of eels, crabs in the genus Chaceon, and holothuroids probably in the genera Mesothuria and Paelopatides.

The results lead to two geobiological questions. (1) Why are chemosynthetic biota limited to mussels and bacterial mats? and (2) why are the mussel colonies apparently restricted to brine flows? The answer to the first may be related to temporal factors. The large variety of deep habitats that support some form of chemosynthetic community indicates that the needs for these faunae can be met by a number of geochemical processes in different geological settings. Adequate and persistent sulfide flux at or near the sediment-water interface is apparently critical. Bacterial mats and mussel colonies may become established more quickly than tubeworm populations, suggesting that these mounds are relatively young features and that Mound $\mathrm{F}$ may be the younger of the two. Alternatively, the sulfide flux at the mounds may be too intermittent temporally and spatially to allow for more extensive community development.

The restriction of chemosynthetic mussels to apparent brine channels is more difficult to explain. It may be that on the mound surface only the brine is charged with adequate methane and/or sulfide to support the symbiotic microbes. This would suggest that sulfide and brine flux from the other mound sediment is minimal. Brine, however, can cause lethal osmotic stress. To survive in these channels, the mussels may be taking advantage of microtopography to keep their bodies just above the brine-seawater interface. Some process allows the mussels to balance the benefits and the toxicity of the brine.

One final observation concerns the lack of any photographic evidence for gas hydrate at the surface of the mounds. Although the mounds are not completely blanketed by the bottom photographs, Fig. 3 does show that the coverage, especially at Mound F, is fairly dense. None of the bottom photographs show features resembling an exposure of gas hydrate, and there is a complete lack of pockmarks that could be associated with surface gas hydrate accumulations releasing into the water column. It is possible that all gas hydrate at these mounds is buried, but it may be that the elevated heat flow and pore water salinities (Coffin et al., 2008; Kastner et al., 2008) have pushed the BGHS all the way to the seafloor. Wood et al. (2008) conclude that the BGHS is at the seafloor at Mound D and shallowly buried at Mound F.

\section{Conclusions}

The surficial characteristics of seafloor mounds (Mounds D and F) in Atwater Valley lease blocks 13/14 along the floor of the Mississippi Canyon have been investigated using bottom photography and acoustic side-scan backscatter and multibeam bathymetric data. The mounds, which measure a few hundred meters in diameter and $\sim 10 \mathrm{~m}$ high, are among a series of mounds in the area targeted for gas hydrate study during 2005 JIP drilling. We infer that the mounds have resulted from fault-related fluid venting. Mound D is the smaller of the two and has authigenic carbonate exposures, indicating slow-to-moderate flux according to the classification scheme of Roberts and Carney (1997). Mound F has been more mud-prone in the recent past, with a visible mud flow on its southeastern flank, a feature interpreted as resulting from a moderate-to-rapid flux environment. Chemosynthetic benthic fauna are restricted to bacterial mats at both mounds and mussels at Mound D. No tubeworm communities are observed at either mound. There are no visible features that indicate the presence of surficial gas hydrate.

\section{Acknowledgements}

Partial support for the research cruises that collected the data for this study was provided by the Department of Energy, National Energy Technology Lab. We would like to thank the captain and crew of the $R / V$ Pelican and the support personnel of the LUMCON Marine Facility for their hard work and exceptional support of the scientific operations during the two research cruises that provided the acoustic and photographic data used for this study. We thank J. Evans and M. Fowler for preliminary estimates of layback and photo analysis, and M. Swartz for shipboard help with the deep-towed camera system. This paper benefited greatly from suggestions by $\mathrm{C}$. Ruppel. We also thank T. Lorenson and G. Barth for helpful reviews of this paper.

\section{References}

Aharon, P., Roberts, H.H., Snelling, R., 1992. Submarine venting of brines in the deep Gulf of Mexico: observations and geochemistry. Geology 20, 483-486.

Brooks, J.M., Wiesenburg, D.A., Roberts, H.H., Carney, R.S., MacDonald, I.R., Fisher, C.R., Guinasso Jr., N.L., Sager, W.W., McDonald, S.J., Burke Jr., R.A., Aharon, P., Bright, T.J., 1990. Salt, seeps, and symbiosis in the Gulf of Mexico: a preliminary report of deepwater discoveries using DSV Alvin. EOS Trans. AGU 71 (45), $1772-1773$.

Carney, R.S., 1994. Consideration of the oasis analogy for chemosynthetic communities at Gulf of Mexico hydrocarbon vents. Geo Mar. Lett. 14, 149-159.

Claypool, G.E., 2006. Cruise Report: the Gulf of Mexico Gas Hydrate Joint Industry Project, Covering the Cruise of the Drilling Vessel Uncle John, Mobile, Alabama to Galveston, Texas, Atwater Valley Blocks 13/14 and Keathley Canyon Block 151, 17 April to 22 May, 2005. Department of Energy. Available from:. http://www. netl.doe.gov/technologies/oil-gas/publications/Hydrates/reports/GOMJIPCruise05. pdf, $196 \mathrm{pp}$

Coffin, R.B., Hamdan, L., Plummer, R., Smith, J., Gardner, J., Wood, W.T., 2008. Analysis of methane and sulfate flux in methane charged sediments from the Mississippi Canyon, Gulf of Mexico. Mar. Petr. Geol. 25, 977-987.

Coleman, J.M., Prior, D.B., Lindsay, J.F., 1983. Deltaic influences on shelf edge instability processes. In: SEPM Special Publication, vol. 33, pp. 121-137.

Cooper, A.K., Hart, P.E., 2002. High-resolution seismic-reflection investigation of the northern Gulf of Mexico gas-hydrate-stability zone. Mar. Petr. Geol. 19, 1275-1293.

Cordes, E.E. Carney, S.L., Hourdez, S., Carney, R.S., Brooks, J.M., Fisher, C.R, 2007. Cold seeps of the deep Gulf of Mexico: community structure and biogeographic comparisons to Atlantic equatorial belt seep communities. Deep Sea Res. Oceanogr. Res. Paper 54, 637-653.

Ellis, M., Evans, R.L., Hutchinson, D.R., Hart, P.E., Gardner, J., Hagen, R., 2008 Electromagnetic Surveying of Seafloor Mounds in the Gulf of Mexico. Mar. Petr. Geol. 25, 960-968.

Evans, R.L., 2004. Cruise Report: R/V Pelican Cruise PE 04-49 Atwater Valley Electromagnetic Survey and Camera Tow. Woods Hole Oceanographic Institution Report Available from: http://woodshole.er.usgs.gov/openfile/of2004-1285/ docs/P1_04_GM_report.pdf, 19 pp.

Evans, J., Fornari, D., Gilbert, L., Boyle, M., Dougherty, J., Hutchinson, D.R., 2004 Archive of Raw Bottom Photographs Taken During Cruise P1-04-GM, Northern 
Gulf of Mexico, 21-24 June 2004. USGS Open File Report 2004-1285 Available from: http://woodshole.er.usgs.gov/openfile/of2004-1285/.

Fornari, D., WHOI TowCam Group, 2003. A new deep-sea towed digital camera and multi-rock coring system. EOS Trans. AGU 84, 69-76.

Francisca, F., Yun, T.-S., Santamarina, J.C., 2005. Geophysical and geotechnical properties of near-seafloor sediments in the northern Gulf of Mexico gas hydrate province. Earth Planet. Sci. Lett 237, 924-939.

Goodwin, R.H., Prior, D.B., 1989. Geometry and depositional sequences of the Mississippi Canyon, Gulf of Mexico. J. Sediment. Petr. 59, 318-329.

Hovland, M., Gudmestad, O.T., 2001. Potential influence of gas hydrates on seabed installations. In: Paull, C.K., Dillon, W. (Eds.), Natural Gas Hydrates: Occurrence, Distribution and Detection. American Geophysical Union Monograph, vol. 124 AGA, Washington, D.C., pp. 307-315.

Hutchinson, D.R., Hart, P.E., 2004. Cruise Report for G1-03-GM USGS Gas Hydrates Cruise, R/V Gyre, 1-14 May, 2003, Northern Gulf of Mexico. U.S. Geological Survey Open File Report OF 03-474 Available from: http://pubs.usgs.gov/of/ 2003/of03-474/, 103 pp.

Joye, S.B., MacDonald, I.R., Montoya, J.P., Peccini, M., 2005. Geophysical and geochemical signatures of Gulf of Mexico seafloor brines. Biogeosciences 2, 295-309.

Kastner, M., Claypool, G., Robertson, G., 2008. Geochemical constraints on the origin of the pore fluids and gas hydrate distribution at Atwater Valley and Keathley Canyon, Northern Gulf of Mexico. Mar. Petr. Geol. 25, 860-872.

Kvenvolden, K.A., 1993. A primer on gas hydrate. In: Howell, D.G. (Ed.), The Future of Energy Gases, pp. 279-291. USGS Professional Paper 1570.

MacDonald, I.R., Reilly, J.F., Guinasso Jr., N.L., Brooks, J.M., Carney, R.S., Bryant, W.A., Bright, T.J., 1990. Chemosynthetic mussels at a brine-filled pockmark in the northern Gulf of Mexico. Science 248, 1096-1099.

MacDonald, I.R., Sager, W.W., Peccini, M.B., 2003. Gas hydrate and chemosynthetic biota in mounded bathymetry at mid-slope hydrocarbon seeps; northern Gulf of Mexico. In: van Weering, T.C.E., Dullo, W.-C., Henriet (Eds.). Mar. Geol., 133-158.

Milkov, A., Sassen, R., 2003. Preliminary assessment of resources and economic potential of individual gas hydrate accumulations in the Gulf of Mexico continental slope. Mar. Petr. Geol. 20, 111-128, doi:10.1016/S0264-8172(03)00024-2.
Roberts, H.H., 2001. Fluid and gas expulsion on the northern Gulf of Mexico continenta slope: mud-prone to mineral prone responses. In: Paull, C.K., Dillon, W. (Eds.) Natural Gas Hydrates: Occurrence, Distribution and Detection. American Geophysical Union Monograph, vol. 124. AGA, Washington, D.C., pp. 145-161.

Roberts, H.H., Carney, R., 1997. Evidence of episodic fluid, gas and sediment venting on the northern Gulf of Mexico continental slope. Econ. Geol. 92, 863-879.

Sager, W.W., MacDonald, I.R., Hou, R., 2003. Geophysical signatures of mud mounds at hydrocarbon seeps on the Louisiana continental slope, northern Gulf of Mexico. In: van Weering, T.C.E., Dullo, W.-C., Henriet (Eds.). Mar. Geol., 133-158.

Sager, W.W., MacDonald, I.R., Hou, R., Bryant, W.R., Doyle, E.H., 2004. Side-scan imaging of hydrocarbon seeps on the Ouisiana continental slope. AAPG Bull. 88 No. 6), 725-746.

Sassen, R., Joye, S.B., Sweet, S.T., Defrietas, D.A., Milkov, A.V., MacDonald, I.R., 1999. Thermogenic gas hydrates and hydrocarbon gases in complex chemosynthetic communities, Gulf of Mexico, Continental Slope. Org. Geochem. 30, 485-497.

Snyder, F.F.C., Muller, L.K., Dutta, N., Hutchinson, D.R., Hart, P.E., Lee, M.W., Dugan, B. Ruppel, C., Woods, W.T., Coffin, R., Evans, R., Jones, E.H., 2004. Seismic analysis and characterization of gas hydrates in the Northern Deepwater Gulf of Mexico. AAPG Bull. 88 (No. 13, Suppl.) Available from: http://www.searchanddiscovery. com/documents/abstracts/annual2004/Dallas/Snyder.htm.

Suter, J.R., Berryhill Jr., H.L., 1985. Late Quaternary shelf-margin deltas, Northwest Gulf of Mexico. AAPG Bull. 69, 77-91.

Weimer P. 1991. Seismic facies, characteristics, and variations in channel evolution, Mississippi Fan (Plio-Pleistocene), Gulf of Mexico. In: Weimer, P., Link, M.H. (Eds.), Seismic Facies and Sedimentary Processes of Submarine Fans and Turbidite Systems. Springer-Verlag, New York, pp. 323-347.

Wood, W.T., Hart, P.E., Hutchinson, D.R., Dutta, N., Snyder, F., Coffin, R.B., Gettrust, J.F 2008. Gas and gas hydrate distribution around seafloor seeps in Mississippi Canyon, Northern Gulf of Mexico, using multi-resolution seismic imagery. Mar. Petr. Geol. 25, 952-959.

Yun, T.S., Guillermo, A.N., Narsilio, J., Santamarina, C., 2006. Physical characterization of core samples recovered from the Gulf of Mexico. Mar. Petr. Geol. 23 893-900. 